\section{Interferon spurs growth of Japanese biotechnology}

Tokyo. Interferon, once thought to be a possible miracle cure for cancer, has emerged as an important element in the growth of Japan's biotechnology industry as a treatment for a type of viral hepatitis prevalent in Japan.

Sales of interferon soared from $¥ 30$ billion (US\$250 million) in 1991 to $¥ 150$ billion last year after the drug was approved by the Ministry of Health and Welfare for treatment of chronic hepatitis $\mathrm{C}$. This year, sales are expected to exceed $¥ 200$ billion, about a third of Japan's total biotechnology market, according to the newsletter Nikkei Biotechnology.

In fact, its accelerated growth has led the Ministry of Finance to call for restraint in its use in fear that it may become a drain on the national health insurance system. A growing number of reports of serious side effects may also limit its market.

In the early 1980s, Japan's fledgling biotechnology industry invested heavily in interferon because it was thought to be a possible cure for cancer. Those hopes proved to be largely unfounded, although the drug has been approved for treatment of a few limited types of cancer.

Sumitomo Pharmaceuticals holds the biggest share of the market - more than a third - because of its large production capacity. Sumitomo licensed cell culture technology from Wellcome plc in Britain and built one of the largest culture plants in the world with three bioreactors of 8,000 litres capacity each. "At the time many people thought they had made a mistake", says Mitsuru Miyata, editor of Nikkei Biotechnology, but Sumitomo's investment has allowed it to respond quickly to increased demand.

Two competitors, Daichi Pharmaceuti- cal and Toray Pharmaceutical, have their own cell-culture technology and two pairs of companies - Takeda Pharmaceutical and Nippon Roche, and Yamanouchi Pharmaceutical and Schering-Plough - apply recombinant DNA technology licensed from US companies. Hayashibara is awaiting approval for its novel technique of massproducing interferon in cancer cells in millions of mice. The demand for interferon is so great that the National Institute of Health, in an unprecedented move, last year accelerated its routine testing of the safety of production lots of the drug.

Japan has about 1.5 million carriers of the hepatitis $\mathrm{C}$ virus, a far larger proportion of the population than in the United States and Europe. Tens of thousands with evidence of active chronic hepatitis in liver biopsies are allowed interferon treatment.

The surge in national health insurance claims for interferon treatment, which now account for about 1 per cent of Japan's total medical bills, has caught the attention of the Ministry of Finance. And in January the Ministry of Health and Welfare, under pressure from the finance ministry, issued a directive to prefectural governments calling for restraint in its use. But it can be argued that conventional treatment of hepatitus $\mathrm{C}$, a disease that often ends in development of liver cancer, would in the long run cost more.

There are also side-effects, including influenza-like symptoms and, in some cases, pneumonia, possibly linked to its use in combination with traditional Chinese medicine.

Nevertheless, it seems that hospitals cannot get enough of the drug, and its use is expected to increase several-fold in the coming fiscal year which begins on 1 April.

David Swinbanks

\title{
Pricing system encourages sales
}

Tokyo. Apart from responding to patient demand, Japanese hospitals have a strong financial incentive for prescribing expensive interferon treatment (see above).

In Japan, hospitals buy and sell their own drugs. Although the Ministry of Health and Welfare sets official prices, hospitals routinely buy drugs at a greatly discounted price from pharmaceutical companies. With demand for interferon so strong, drug companies do not have to offer large discounts. But as a course of treatment with interferon typically costs several million yen (several tens of thousands of dollars) for a patient with hepatitis $C$, even a small discount can mean a sizeable profit. One result of the system is the highest per-capita consumption of drugs in the world.

Apart from cost, overprescription of expensive drugs has serious medical conse quences. Japanese doctors routinely give large doses of expensive antibiotics to patients after minor operations even if they show no signs of infection. As a result, many of Japan's hospitals are now infected with resistant strains of bacteria that can be lethal to patients with weak immune systems.

The Ministry of Health and Welfare has for years tried to separate the prescription and selling of drugs by urging hospitals to use outside pharmacies, and it is gradually reducing the maximum discounts that drug companies can offer.

D.S.

\section{Vaccination may} be a culprit

Tokyo. The prevalence of hepatitis $C$ in Japan may in part be an unfortunate product of modern medicine.

The original cause of the high incidence of hepatitis $C$ in Japan and other neighbouring Asian nations is not understood. However, it is believed that the common practice of reusing needles in mass vaccination pro grammes carried out several decades ago in Japanese schools helped to spread the virus. Several lawsuits have been filed by patients blaming the vaccination programmes for their infection but it is impossible to trace the source of infection with certainty.

Another contributing factor was the absence of routine screening for the virus in the blood supply until detection kits for the hepatitis $C$ virus were developed following characterization of the virus in 1988. As a result, about 10 per cent of patients receiving blood transfusions in Japan were infected with the virus because of the high incidence of hepatitis $\mathrm{C}$ among blood donors. D.S.

\section{Tokyo University names new head}

Tokyo. Faculty members of Tokyo University, Japan's leading national university, last week elected a president to replace Akito Arima, a leading force for reform of Japan's universities.

Arima's successor is Hiroyuki Yoshikawa, a former dean of the faculty of engineering

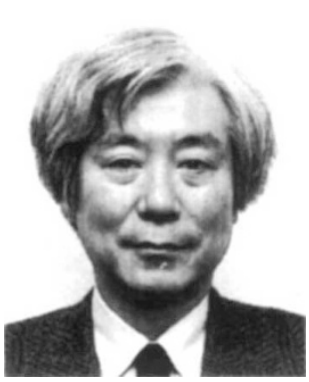

Hiroyuki Yoshikawa and now a special adviser to Arima, whose four-year term ends on 31 March. Yoshikawa is known for his work on the Intelligent Manufacturing Systems (IMS) project, which is intended to combine the industrial forces of

Japan, Europe, North America and Australia to develop a fully automated manufacturing system (see Nature 355, 755; 1992).

But Yoshikawa will find it hard to match the achievements of Arima, who has not only helped universities to get substantial new government funding for renovation and for research but has also initiated the first external review of a university department (see Nature 360, 403; 1992). Yoshikawa must decide whether to extend the review process to other departments.

David Swinbanks 